\title{
Problems of Working Journalists in Pakistan
}

\author{
* Dr. Ayesha Qamar, Lecturer \\ ** Dr. Samia Manzoor, Assistant Professor (Corresponding Author) \\ *** Ms. Aqsa Iram Shahzadi, Assistant Professor
}

\begin{abstract}
Journalists around the world are facing difficult situations while pursuing their careers. The situation of Pakistani journalists is not different. Lack of safety and other incentives offered by their organizations are the major problems faced by them. The present study aimed to analyze the problems faced by Pakistani journalists regarding their professional chores. The researchers used Maslow's hierarchal model and Herzberg's Motivation Hygiene theory to give a comprehensive picture of working conditions and their effects on journalists' performance. The quantitative approach was utilized by the researchers in the form of a survey method to highlight the problems faced by journalists. The results showed that the majority of journalists are not satisfied with their current job scenarios. They are confronting too many difficulties including Job security, threats, professional training, tight deadlines, and excessive work hours. Moreover, the respondents unveiled that these problems are adversely affecting their work performance by causing certain physical and mental health issues.
\end{abstract}

Keywords: Problems of Journalists; Professional Training; Work Performance; Job Dissatisfaction; Job Stress

\section{Introduction}

Journalism is one of the most fundamental building blocks of a balanced society. Only an organized and disciplined press ensures the stability of industrialized social systems. News media aim to provide a free flow of information to the public and also a free market place where new ideas are proposed and adopted every day (Resources, 2016). From the very beginning, journalism is a source of business and development for those who are linked to it. Governments and other entities also consider media organizations as a source to influence people and to control societies. Using journalism for different purposes has become the need of the day (McQuail, 2013). Many public opinion surveys revealed that the public considers journalists as the least trustworthy entity. For the public, journalists are either money-grabbing agents or obliging the political elites. This is because the expansion of media is briskly decreasing the value of journalists in many countries (Shameer, 2018).

According to Brédart \& Holderness (2016) today journalism practices are greatly expanding but the values are briskly decreasing. The normative standards of the workplace and professional life are declining and the same is happening to the news media industry. Journalists and their unions are facing certain problems concerning their rights' like provision and unpaid/low salaries. As journalism is one of the reputable professions but not providing decent salaries to its employees. Newspapers are already facing unstable economic conditions, perpetuated with recent economic changes that are putting journalists under pressure. They are torn between either to follow their passions or quit for extra income. Due to unstable conditions, some journalists receive monthly salaries in portions ( ElSheikh, February 27, 2018). Similarly, Physical attacks against journalists and media professionals are not a new phenomenon today. Like other media professionals, journalists also face physical threats and harassments. Even the cases of threatening and harassing the journalists by using social networking sites are also common today (n.d., 2016). According to Elliott, Elbahtimy \& Srinivasan (2012) journalists all over the world are increasingly facing threats, physical harassment, and even murders. This is not only an explicit infringement of Human Rights but also, an alarming situation for society. Their exploitation means refraining from freedom of expression and therefore, freedom of the

* Department of Communication \& Media Studies, Fatima Jinnah Women University, Rawalpindi

** Department of Communication Studies, Bahauddin Zakariya University, Multan

Email: samia.manzoor@bzu.edu.pk

*** Department of Communication Studies, Bahauddin Zakariya University, Multan 
right to know. It is also assumed that democratic systems are capable enough to provide safety to the journalists. However, today the more democratic a society is, the more threats and physical assaults are faced by the journalists (Siddiqui, 2016). Furthermore, in many countries like New Zealand, Australia, the professional development of the journalists is under discussion. In many regions where journalism is considered as a key to information, the development and progress of this profession are absent. This is because journalism contains a professional ideology that individuals can only attain through professional training and guidance (Murphy, 2019). Today, the world and professions are vastly expanding, so more skills and expertise are needed. Therefore, professional life also demands journalists to do multi-tasking and adopt various liabilities all at the same time. This is done by working as a journalist in media organization and also running personal blogs or working as freelance journalists in the other news media organizations (Rotwilm, 2014). Another major issue faced by journalists is work stress accompanied by long-working hours as journalism has become one of the most stressful professions today (Shalini, 2017).

\section{Problem Statement}

Due to the existing hardships faced by journalists, their performance is rapidly declining. Workplace environment, opportunities, safety, harmony, relationships, and respect ensure the employees' contributions. Likewise, in news media organizations job security, competitive salaries, workautonomy, and others are the key indicators of the working conditions (Shameer, 2018). Maslow's Hierarchy of Needs theory (1943) clearly mentions the basic needs of a human being as well as an employee. Likewise Herzberg's Hygiene Motivation theory (1959) also stresses on the availability of certain conditions at a work place to attain good performance by the employees. Using the theoretical support from both of these theories the present research highlighted the problems of working journalists of Rawalpindi/Islamabad and its effects on their performance.

\section{Literature Review}

Journalism is an honorable profession. It gets attention from both political bodies and the public of a state. Everyone especially elites always keeps an eye on journalists to dominate the dissemination of news. This dominance affects the quality of work and journalists also face many problems due to this external pressure (Ibbi, 2016). In the same context, Journalists worldwide are facing numerous professional challenges that are causing adverse impacts on their work performance. Here in this section, the researchers will review some supportive literature that will further strengthen the basic concept of the present study:

Further, several studies explored the raising concern in the extent of low or unpaid jobs of journalists. To investigate this Thurman, Cornia, \& Kunert (2016) analyzed the employment conditions of journalists in the United Kingdom. The researchers utilized the survey method and found that the majority of the journalists have gross salaries of less than $19,200 £$ and $83 \%$ of journalists in their late twenties earn less than 29,000£ annually. Another study conducted by Ireri (2016) also validated the notion of low and unpaid salaries to the journalists in Kenya. The results of his study revealed that out of $n=504$ participants, $61 \%$ of the journalists were dissatisfied with their jobs due to comparatively low salaries. Therefore, the researcher argues that poor income is causing certain negative impacts on journalists' work performance in Kenya.

Young \& Carson (2018) examined the recruitment of journalists in Australia, the frequency of job advertisements, and their salaries. According to the results, job advertisements were being given more than four times a year but still, a very low number of individuals were selected. Also, the recruited ones were working on very low salaries which means that journalists and their wellbeing were not the priority of the news media industry.

To investigate this phenomenon, Murphy (2019) conducted an analysis and surveyed 885 journalists all over the United Kingdom. Findings of this study unveiled that workload has significantly increased for the journalists in the UK. Most journalists work in both print as well as electronic media. All the participants showed a deep concern towards training and development programs, because to adopt new job roles and perform well suitable training is important.

Muala (2017) also analyzed the work stress faced by journalists in Jordan. The results revealed that journalists were facing work stress challenges as they had long working hours and tough topics to cover. They were not satisfied with their working conditions as their management was not supportive causing them higher stress. Therefore, the researcher emphasized the importance of supportive colleagues, workload management to fight with job stress among the journalists. 
Shameer (2018) reviewed the literature concerning the working conditions of journalists in different regions. The researchers found that in the majority of countries, journalists work under adverse circumstances. They mainly have issues concerning low salaries, protection, and also lack of autonomy. Mostly they remain dissatisfied with their working conditions with tight deadlines. Therefore, the researchers concluded that journalists face poor mental and physical outcomes due to an increasing job discontent among them. Liu, Xiaoming, \& Wen (2018) analyzed the impacts of problems faced by journalists in Chinese news media. The researchers surveyed 347 individuals of five Metropolitan newspapers in China. Findings of their study revealed that Chinese journalists were not dissatisfied with their jobs as they were receiving all the necessary benefits from their organizations. They were paid well, offered professional development programs and their jobs were secure. Therefore, the researchers suggested that if the news media industry tends to consider journalists as an important part of their organization, they will perform well to achieve the organizational goals.

\section{Theoretical Framework}

\section{Abraham Maslow's Hierarchy of Needs}

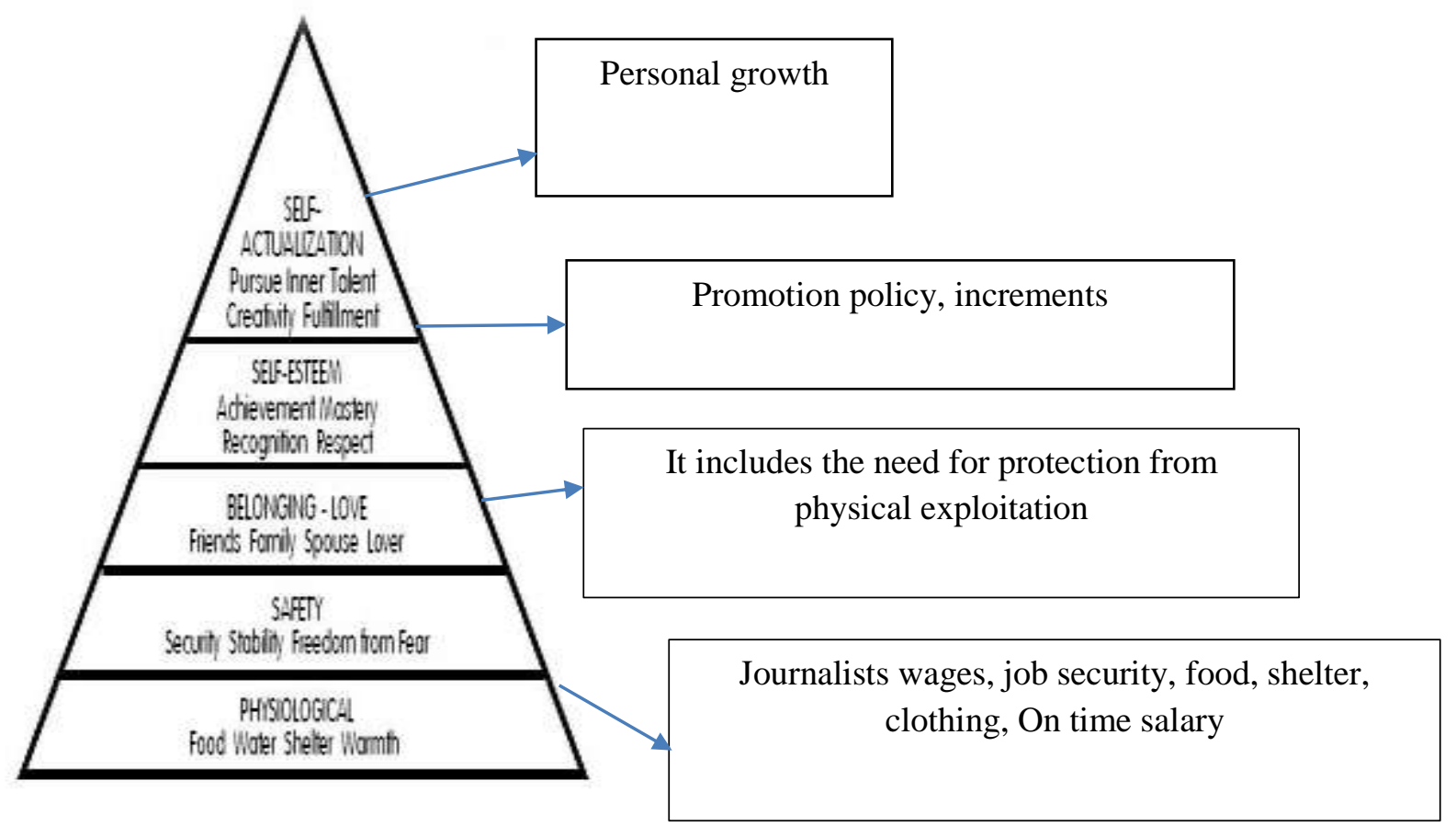

Fig 1: (McLeod, 2018)

Maslow's Hierarchy of Needs theory (1943) supports the conceptual background of this study. Maslow believed that motivation is influenced by certain needs. When one need is fulfilled, an individual moves to fulfill the next (McLeod, 2007). In this context, one of the most important indicators of the working conditions of journalists is their level of job satisfaction. In some cases, it is linked to their perceived autonomy or freedom. In the United States, for example, declining levels of job satisfaction and perceived autonomy have gone hand-in-hand since the early 1970s (Beam, 2006). According to Ofili, Tobin, Ilombu, Igbinosun, \& Iniomor (2014), job satisfaction among journalists is directly linked with their working environment. If there is a higher level of stress, it can be because of tight deadlines, long working hours, unsafe job environments, and others. von Rimscha (2015) examined the job satisfaction level among media workers. The results unveiled that people who work in production departments were comparatively less satisfied with their jobs than the others. The researcher also found that autonomy was an important determinant of job satisfaction. However, media sellers were satisfied with their jobs as they did not have any issues concerning job autonomy. Journalists are committed to devoting their efforts to their profession. This commitment is seen when journalists have poor work conditions and tough working hours. Sometimes this commitment gets affected by high levels of stress, strict working deadlines, and others (Schallom, 2012). 


\section{Hygiene Motivation Theory}

Herzberg's Hygiene Motivation also known as Two-Factor theory. It is the second theoretical background supporting the concept of this study. Originally proposed by Fredrick Herzberg, this theory was first published in "The motivation to Work" (1959). Herzberg's Hygiene Motivation theory tends to focus on individuals at work as the motive is to investigate the factors that please or displease them. According to Herzberg (2009), certain factors adversely affect the job performance of individuals. In this regard, like other professional fields, journalists also face certain problems i.e., job stress that affects their psychological and physical health. This also affects their organizational performance and sometimes they also intend to leave their jobs (Ofili et al., 2014). Similarly, many journalists also claim that they have to oblige their senior executives for news writing. They keep the "media buyers" and" owner's" interest under consideration which causes them psychological pressure affecting their work performance (Jamal \& Awaisi, 2012). Furthermore, due to the development of new media technologies, journalists require relevant skills and training. Due to the absence of these skills they face certain challenges which also cause them stress and affect their performance (Cabedoche, 2019).

Based on the literature and conceptual framework two following research questions were formulated for the current research

R1: What are the problems that journalists of Rawalpindi and Islamabad face in their work environment?

R2: What is the impact of the problems that journalists face, on their work performance?

\section{Methodology}

This study is exploratory as exploratory research is a method which helps to find out what is new and unique. without revelation of something new, a study will standstill (Swedberg, 2018). To collect quantitative data, the researchers used closed-ended questions as a research tool. Likert scale measurement is used to collect the responses of the participants. The study utilized a Web survey to access potential respondents as web-based surveys are highly beneficial regarding their speed, quality, and cost. They are comparatively faster and efficient than the traditional approaches of the data gathering process (Heiervang \& Goodman, 2011). A total of $n=191 \quad((M=1.31 S D=.567)$ participants participated in this study out of which 61.5\% $(n=123, M=1.31, S D=.576)$ were males and $35.6 \%(n=68, M=1.31, S D=.553)$ were female journalists from the twin cities i.e. Rawalpindi and Islamabad.

\section{Population and Sampling}

The population of this study comprised of all the journalists from the cities of Rawalpindi and Islamabad. To select the sample of the study the researchers used a convenience sampling technique. This technique was suitable because it helped to simply access the participants as they were the "convenient source of data" for the researchers (Lavrakas, 2013) The researchers sent the questionnaire through emails to the potential respondents and gathered the responses. The respondents participated as they were willing to be a part of this research study.

\section{Variables}

\section{Independent Variables}

Physiological needs include salary, job security (salary can help to provide shelter, water, and food), life security, working hours, promotion policy, and professional training and development. Multiple questions were asked by the journalists to measure the above-mentioned variables using the Likert Scale as strongly agree $=5$ to strongly disagree $=1$.

\section{Dependent Variable}

The level of performance means that how much the journalist is productive in his/her organization. A sequence of questions was asked to measure the journalist's performance using the Likert Scale as strongly agree $=5$ to strongly disagree $=1$

\section{Data Analysis and Results \\ Reliability}

The Cronbach alpha is used for instrument reliability. Twelve questions were asked from the respondents for measuring the problems of journalists and its effects on their performance. The alpha coefficient for 12 items is 0.869 which shows that items have quite high internal consistency. The universal law of thumb for Cronbach's alpha is 0.70 and overhead is good, 0.80 and overhead is better, and .90 and overhead is best. 


\begin{tabular}{llll}
\hline \multicolumn{4}{c}{ Case Processing Summary } \\
& Valid & $\mathrm{N}$ & $\%$ \\
Cases & 191 & 100.0 \\
& Excluded $^{\mathrm{a}}$ & 0 & .0 \\
& Total & 191 & 100.0
\end{tabular}

a. Listwise deletion based on all variables in the procedure.

\section{Reliability Statistics}

Cronbach's $\quad \mathrm{N}$ of Items

Alpha

.869

12

For addressing the research question 2 Multiple linear Regression Model for measuring the effect of working problems on their job performance.

\begin{tabular}{lllllll} 
Anova & & & & & \\
\hline Model & & Sum of Squares & df & Mean Square & F & Sig. \\
\hline \multirow{4}{*}{1} & Regression & 52.540 & 6 & 8.757 & 10.789 & $.000^{\mathrm{b}}$ \\
& Residual & 149.335 & 184 & .812 & & \\
& Total & 201.874 & 190 & & & \\
\hline
\end{tabular}

a. Dependent Variable: performance

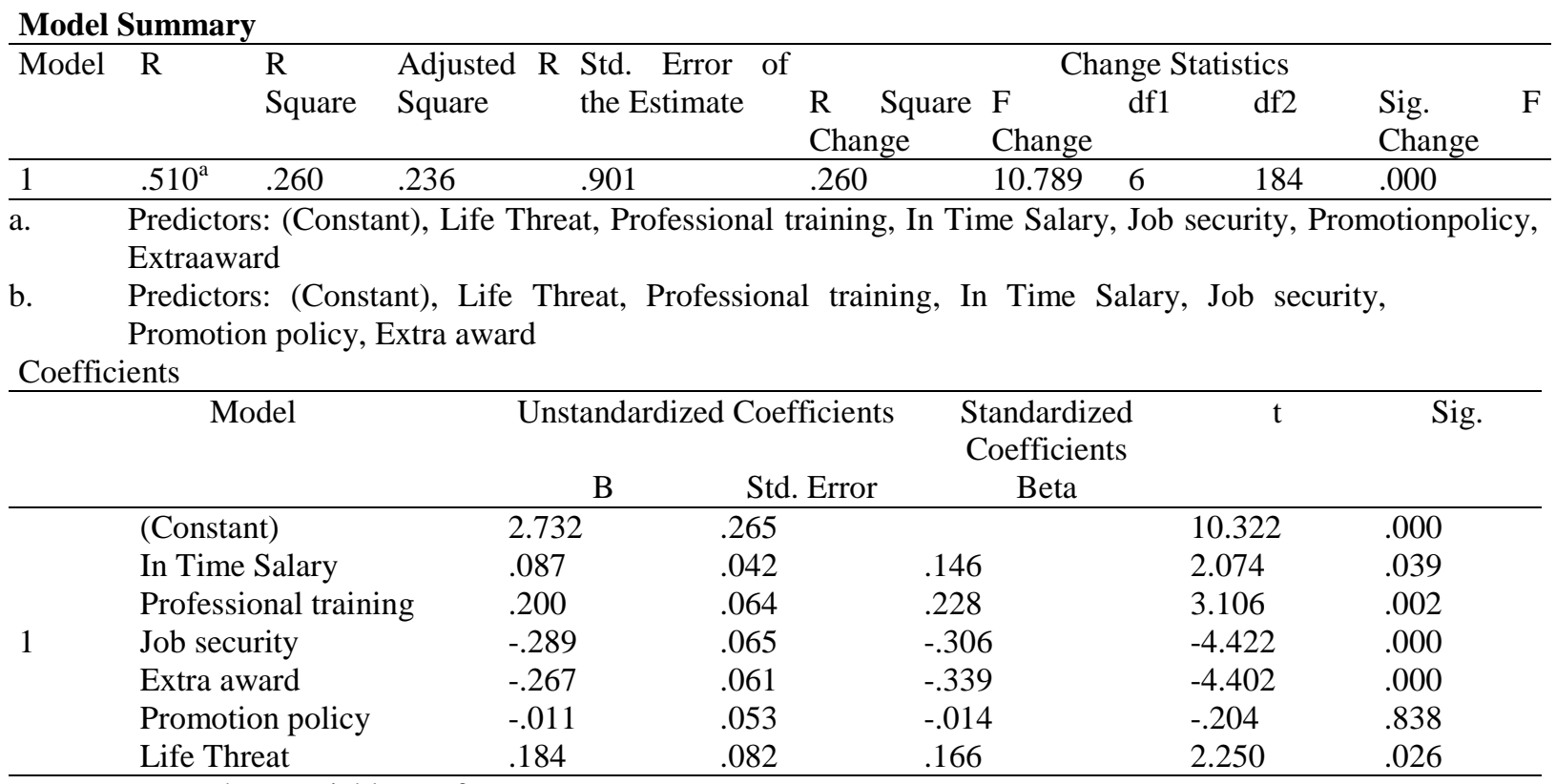

a. Dependent Variable: performance

In ANOVA Table sig $=.000$ means that predictors can calculate the significate amount of variance that is called the performance of journalists. So the regression model is significant. It was observed that the multiple linear regressions used, identified the strength of the effects that the independent variable(s) can have on a dependent variable. F statistics is $f=10.789$ which affirmed that our assumptions are highly significant.

For ANOVA table (test using alpha .05)

$\mathrm{F}(6,184)=10.789 p>.001, \mathrm{R}^{2}=.23$

From the Coefficients table regression equation of this research looks like

The regression equation of performance $=2.732$ (constant) +.087 (in time salary) + .002 (professional training) +.184 (life threat) -.289 (job security) -.267 (extra award)-.011(promotion policy).

Correlations and Standard Deviations are mentioned in the table. The combination of variables used to predict journalist's performance, were, in time salary, job security, professional training, extra award, and life threats were statistically significant, $p<0.05$. While promotion policy is not statistically significant with the performance of journalists as $\mathrm{p}>0.05$. 
To examine the impacts of problems faced by journalists on their professional performance, the researchers used a multiple linear regression model. Table 2 contains the detailed results of Multiple Regression Analysis. Therefore the outcomes unveiled that with the significance value of $.000(p \geq .05)$ problems faced by journalists are strongly affecting their work performance.

\section{Discussion}

RQ1: What are the issues and problems of working journalists in Pakistan?

Table 3 Descriptive Statistics for the Job Type of the Respondents

\begin{tabular}{lll}
\hline Job type & Frequency & Percentage \\
Contract & 142 & $74.3 \%$ \\
Part Time & 39 & $20.4 \%$ \\
Permanent & 10 & $5.2 \%$ \\
\hline
\end{tabular}

Table 1 contains the descriptive statistics to graphically represent the job type of potential respondents. It is showed that $n=142$ or $74.3 \%$ of participants had jobs on a contract basis. $N=39$ or $20.4 \%$ of journalists were working on a part-time basis and the rest of $n=10$ or $5.2 \%$ had permanent jobs in news media organizations. These statistics show that majority of journalists are not hired permanently but instead, they are the majority on a contract basis which is an alarming condition. Due to a lack of job security journalists could not perform up to the mark in their careers.

Furthermore, the researchers analyzed the types of problems faced by journalists in Rawalpindi and Islamabad. Participants unveiled that they face certain interferences from both external and internal sources ( $n=176$ or $92.1 \%)$. Also affirmed by (Garcia, 2015) as she argued that many external and internal factors deeply influence news content. These influences lead to represent an event in a framed manner. Finally, they decide what to be regarded as "news" and given priority. Similarly, the world is rapidly changing and requires journalists to cope with the new environment and technologies. This not only helps them to keep pace with the new trends but also supports them to learn new skills (Spilsbury, 2014). However, the majority ( $n=178$ or $93.1 \%)$ of the respondents revealed that they lack any professional training from their organizations.

Journalism is one of the most stressful professions. Excessive work and pressure cause mental and physical ailments among journalists. Also, it affects the work quality and performance of the designated journalists (Shalini, 2017). Research also authenticated this notion as according to the $n=$ 181 or $9.7 \%$ ) of participants they are facing extreme physical stress. Likewise, 181 or $94.7 \%$ of respondents also revealed that they are facing mental stress due to excessive workload and tight deadlines. Due to this, besides certain physical ailments, Post-Traumatic Stress disorder is one of the most common psychological disturbances. Even covering violent news reports also influence mental health in an adverse manner (Muala, 2017).

Table 4 Descriptive Statistics of Problems Faced by Journalists

\begin{tabular}{clcc}
\hline $\mathbf{S} / \mathbf{R}$ & \multicolumn{1}{c}{ Variables } & Mean & SD \\
$\mathbf{1}$ & I often face threats from colleagues and external sources & 1.09 & .420 \\
$\mathbf{2}$ & I often confront to unpaid wage & 1.02 & .217 \\
$\mathbf{3}$ & I am not given any professional training from my organization & 1.09 & .352 \\
$\mathbf{4}$ & I often work for extra hours to meet the deadlines & 1.10 & .435 \\
$\mathbf{5}$ & I can be forced to resign any moment & 1.09 & .407 \\
\hline
\end{tabular}

The issue of unpaid salaries for the journalists initially rose during February 2019 and is still unresolved. In this regard, both the Pakistan Federal Union of Journalists and the International Federation of Journalists expressed serious concern. They highlighted the issues and also demanded the Government of Pakistan to immediately resolve the issue (Journalism Pakistan, 2019). However, the researchers also found that still $n=173$ or $90.5 \%$ of participants also have unpaid salaries for months (Vogel, 2017). To achieve a high level of organizational commitment and objectives, journalists often have to work for excessive hours. This causes them to develop stress which has detrimental impacts on their work performance (Huda \& Azad, 2015). According to the respondents, $n=185$ or $96.8 \%$ of respondents, they work for even extra hours to meet the deadlines. The rise of new challenges and the extended size of media audiences have also burdened the journalists to work more. Media companies are inclined towards the content which affects the journalists' welfare and working conditions (Vogel, 2017). 
Table 5 Descriptive Statistics for the Impacts of Problems Faced by Journalists on Work Performance

\begin{tabular}{cllc} 
S/R & \multicolumn{1}{c}{ Variables } & Mean & SD \\
$\mathbf{1}$ & Problems often infer my ability to perform well in the office & 1.08 & .396 \\
$\mathbf{2}$ & Problems faced at work often cause me mental disturbance & 1.13 & .570 \\
$\mathbf{3}$ & Excessive work often causes me stress & 1.05 & .329 \\
$\mathbf{4}$ & Excessive work often creates physical health issues for me & 1.08 & .396 \\
$\mathbf{5}$ & Problems faced at work often affect my overall performance & 1.09 & .407 \\
\hline
\end{tabular}

The table shows that majority of journalists faces the mental disturbance, stress, physical health issues in job. Furthermore, both job satisfaction and professional commitment are important for success in any profession. Also, those who are privileged with job security, consider journalism more than a "job" (Memon, 2011). This is because if employees are satisfied with their job they tend to be more committed to their profession. Job satisfaction is indeed a determinant factor concerning the employees' organizational commitment and work performance (Bakan, Buyukbese, Ersahan, \& Sezer, 2014). However, in this analysis, the $n=176$ or $92.1 \%$ of respondents revealed that they do not have any job security rather they are highly uncertain about their jobs.

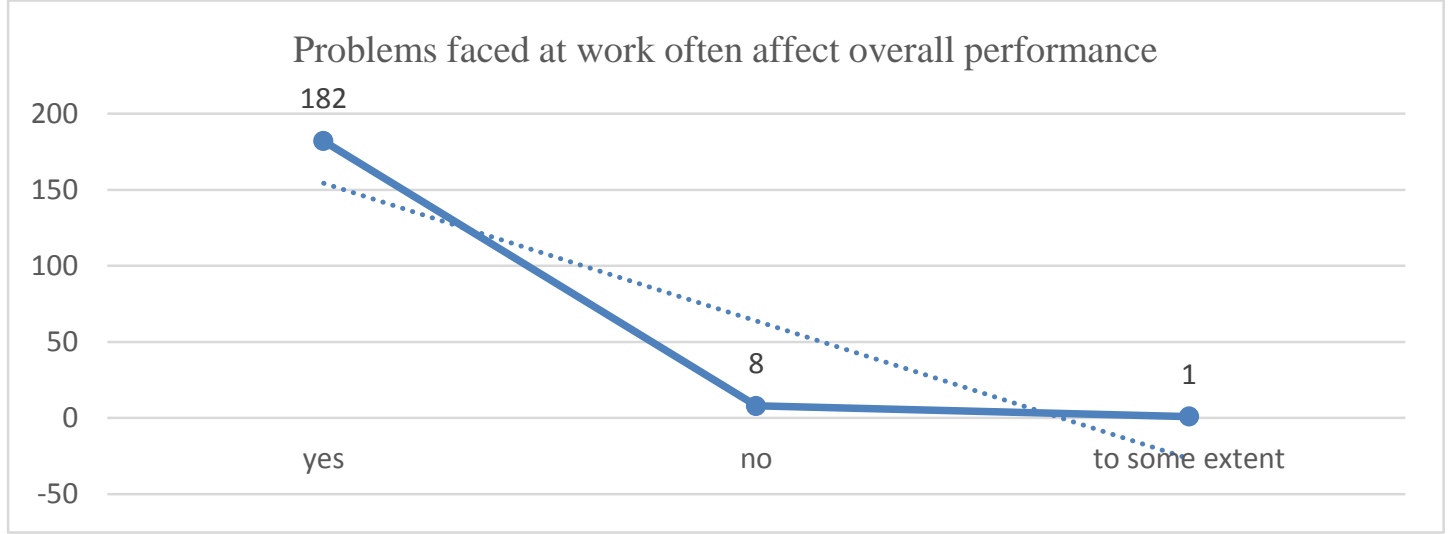

Figure 1 Descriptive Statistics for Impacts of Problems on Journalists' work Performance

Journalists have certain professional demands to fulfill but cannot perform their duties on their own. They face pressure from different external and internal entities. In simple words, this makes a journalist behave in a way he might not want to (Ingram \& Estate, 2019). Thus, $N=177$ or $92.6 \%$ of participants in this analysis, unveiled that both external and internal problems i.e. pressure; excessive work hours, and the influence of others on their work performance. To meet the professional requirements, journalists often face immense pressure. Several studies also validate the significant relationship between professional stress on journalists and their poor performance (Rameez, Huda, \& Ali, 2015). Hence, the majority of ( $n=182$ or $95 \%)$ respondents revealed that problems affect their overall journalistic practices in daily routine activities.

Pressure, harassment, murders, professional rights violation, and abduction all are common to restrict the freedom of expression. Journalists are facing these situations almost all around the world leading to serious concerns for the media professionals. This is not only an explicit infringement of Human Rights but also, an invasion on the right of free access to information. Every time a journalist is killed or harassed, our right to freedom of information gets inhibited (Elliott et al., 2012). Likewise, Journalists in Pakistan are working in extremely threatening situations. Besides job security, they also face threats from various sources (Dawn, November 26, 2011). Especially, political and governmental sources tend to pressurize more than others. Freedom of the press is often undermined by pressure groups even causing brutal murders of many journalists in Pakistan (Aslam, 2015). Due to the increasing number of threats to the journalists, the journalist unions all over Pakistan are uncertain about the safety of their members. Since 2000, more than 100 journalists brutally killed in Pakistan and several others are facing harassments (Rehmat \& Alam, 2014). According to Hussain (2017), security agencies and government officials have harmed many journalists. Even, bloggers who got arrested for revealing against political parties were arrested and later faced much humiliation.

Likewise, in this study, the majority of the respondents $(n=142$ or $74.3 \%)$ reported that they do not have any protection from potential harms, medical facilities. Journalists who get injured during duty hours are not provided medical aid because they do not have the contract letter. This is because, 
besides external threats and harassments, journalists in Pakistan are also confronting internal threats including job security (The Express Tribune, 2020). Similarly, the journalists work for long hours which affects their performance. Working more than eight hours inevitably harms their physical and mental health. Like other organizations, work stress on media professionals, particularly on journalists, is a highly considerable phenomenon today. It is a black plague for journalists who tend to work for the betterment of society. Despite technological integration, journalists are stressed with the workload and tight deadlines (Shalini, 2017). Also, unpaid/low salaries lead a journalist to either oblige an external "gatekeeper" or it causes them psychological distress. A committed, happy, and satisfied journalist tends to perform well and works to achieve his organizational goals (Eijaz, Rahman, Ahmad, \& Butt, 2014).

Another reason is the lack of professional training for these journalists. Sometimes, English news journalists are highly prioritized than journalists from Urdu news sources resulting in low or even denied salaries (Eijaz et al., 2014). Journalists in Pakistan are usually not well paid and their media organizations deny their employment rights. They get pressurized and sometimes also get indulged in unethical practices (Adnan, Ali, \& Aslam, 2019).

Further, in such intense situations, poor performance and professional stress are undeniable. As professional stress and pressure, both are among the common challenges to the work performance of the employees. Excessive workload, tight deadlines, and pressure from colleagues or external forces adversely influence one's ability to perform well (Ajayi, 2018). This trend is also affirmed by the Abraham Maslow Hierarchy of Needs theory and Herzberg Hygiene motivation theory. According to Taormina \& Gao (2013), a strong correlation between needs described by Maslow and an individual's professional life is a key determinant of better performance. In this regard, a journalist will be comparatively more satisfied if his organization will gratify his five prescribed needs. The phenomenon of job satisfaction is well understood by both Herzberg's Hygiene Motivation theory and Abraham Maslow's Hierarchy of Needs theory. Employees tend to be highly motivated and committed to their work if they are satisfied with their job. Otherwise, detrimental impacts on both psychical and psychological health are inevitable leading to poor performance (Islam \& Ali, 2013). In this regard, many times journalists have to do more work and less appreciation. Long work hours and no appreciation are two of the most complained factors by the journalists. Although stress at the workplace is also an important part of media jobs but journalists need to be treated well and appreciated fully (Hare, 2016). They usually have tough working hours, challenging assignments, and busy work environments. This causes stress on them and affects their working abilities (Huda \& Azad, 2015). These professional problems cause low morale among the employees. This can be caused by different social factors including pressure from different sources, competitive lifestyle, professional grudges, job insecurity, and physical threats. Job incentives, insurance, job security, and professional autonomy can help to increase the morale of the news media employees (Vijayan, 2017).

\section{Conclusion}

In this study, the researchers examined the problems faced by journalists in the Twin cities i.e. Rawalpindi \& Islamabad, and analyzed the extent to which these problems are affecting their work performance. Surveying $n=191$ journalists validated the idea of restrictions on journalists and pressure from both internal and external sources. Moreover, we also found that they are facing mental and physical health problems dues to long working hours, stressful workforce conditions, and low/unpaid salaries. These problems are largely affecting their work performance and many of the respondents also revealed that they want to quit their jobs. They lack freedom of expression, job security; employment rights, and even their lives are under constant danger. Journalists face threats and confront difficult situations that limit their ability to play their watchdog role. Today, the media industry is completely market-driven and media organizations do not value their presence. Disruption and devaluation of journalists is highly problematic for the right of freedom of expression and right to information (Wahl-Jorgensen et al., 2016)

Especially, in Pakistan, the role of journalists is highly influential. However, during the past few years many journalists are threatened, killed and the majority of them are facing stressful conditions and unpaid salaries. Loss of life, unpaid salaries, fear of losing their jobs, and others are serious concerns for the journalists in Pakistan. Their contributions are taken for granted and they are devalued by their organizations (Aslam, 2015). Media tycoons are expanding their business and buying television and radio channels but, they are not willing to pay the journalist who has 
contributed to strengthening the democracy (Khan, 2020). Therefore, media being the fourth pillar of a democratic state, are working for the progress and solidarity of the Pakistani nation. Journalists in this regard should be provided proper training, job security, autonomy, and freedom from pressure. Their problem and concerns should be eradicated at every level so that, they may contribute more to the welfare of a common man in Pakistan. This because, journalists face threats, pressure, and other certain problems still they do not give up. Journalists inform and keep a balance between different sections of society. They inform the people about laws, government, and social structure. Therefore, to sustain this flow of information the journalists deserve better opportunities and an autonomous working environment (Sonnemaker, 2015).

\section{References}

Adnan, M., Ali, A. \& Aslam, S. (2019). Economic Issues and Ethical Journalism in Pakistan: Prospects and Challenges. Global Social Sciences Review, IV(I), 11-22. https://doi.org/10.31703/gssr.2019(iv-i).02

Ajayi, S. (2018). Effect of Stress on Employee Performance and Job Satisfaction: A Case Study of the Nigerian Banking Industry. SSRN Electronic Journal. https://doi.org/10.2139/ssrn.3160620

Aslam, R. (2015). Media, politics, and the threats to journalists in Pakistan. Pacific Journalism Review, 21(1), 177-194. https://doi.org/10.24135/pjr.v21i1.156

Bakan, I., Buyukbese, T., Ersahan, B., \& Sezer, B. (2014). Effects of Job Satisfaction on Job Performance and Occupational Commitment. INTERNATIONAL JOURNAL OF MANAGEMENT \& INFORMATION TECHNOLOGY, 9(1), 1472-1480. https://doi.org/ 10.24297/ijmit.v9i1.668

Beam, R. A. (2006). Organizational goals and priorities and the job satisfaction of U.S. journalists. Journalism and Mass Communication Quarterly, 83(1), 169-185. https://doi.org/ $10.1177 / 107769900608300111$

Brédart, H. \& Holderness, M. (2016). Rights and Jobs in Journalism. Brussels, Belgium: European Federation of Journalists. retrieved by http://europeanjournalists.org/wp-content/uploads/2016 /11/EFJ_handbook_web_cor.pdf

Cabedoche, B. (2019). New challenges for journalism education A contribution to Unesco politics To cite this version: HAL Id: hal-02025490 New challenges for journalism education A contribution to Unesco politics.

Eijaz, A., Rahman, B. H., Ahmad, R. E., \& Butt, J. A. (2014). Challenges and Options for Pakistani Media in the 21st Century. Journal of Political Studies, 21(1), 243.

Elliott, S., Elbahtimy, M., \& Srinivasan, S. (2012). Threats to the Right to Life of Journalists. CGHR Working Papers, (4). Centre of Governance and Human Rights, University of Cambridge. retrieved from https://www.repository.cam.ac.uk/bitstream/handle/1810/245114/CGHR_ WP_4_2012_Journalists-Report.pdf?sequence $=4 \&$ isAllowed $=y$

El-Sheikh, S. (February 27, 2018). How are Journalists Coping with Low Salaries? The Daily News Egypt. retrieved from https://www.pressreader.com/

Garcia, K. (2015). Internal and External Influences on Individual Journalists. Journalism. Retrieved from https://digitalcommons.calpoly.edu/joursp/99/

Hare, K. (2016). Journalism is a stressful career, but work doesn't have to be miserable - Poynter. Retrieved March 12, 2020, from https://www.poynter.org/reporting-editing/2016/journalismis-a-stressful-career-but-work-doesnt-have-to-be-miserable/

Heiervang, E., \& Goodman, R. (2011). Advantages and limitations of web-based surveys: Evidence from a child mental health survey. Social Psychiatry and Psychiatric Epidemiology, 46(1), 69-76. https://doi.org/10.1007/s00127-009-0171-9

Herzberg, F. (2009). Frederick Herzberg The hygiene Motivation theory. Chartered Management Institute, 1-2. Retrieved from https://www.managers.org.uk/ /media/Campus Resources/ Frederick Herzberg - The hygiene motivation theory.ashx

Huda, K. N., \& Azad, A. K. (2015). Professional Stress in Journalism: A Study on Electronic Media Journalists of Bangladesh. Advances in Journalism and Communication, 03(04), 79-88. https://doi.org/10.4236/ajc.2015.34009

Hussain, I. (2017). Pakistan Journalists Cite Growing Threats From Government, Militants Alike | Voice of America - English. Retrieved March 12, 2020, from https://www.voanews.com/eastasia-pacific/pakistan-journalists-cite-growing-threats-government-militants-alike 
Ibbi, A. A. (2016). The battle for professionalism in journalism in Nigeria amidst unethical practices. Journal Mass of Communication and Journalism, 6, 301. DOI: 10.4172/21657912.1000301

Ingram, D. \& Estate, P. H. (2019). Chapter 58: Pressures on journalists. Retrieved March 11, 2020, from https://www.thenewsmanual.net/Manuals\%20Volume\%203/volume3_58.htm\#codes

Ireri, K. (2016). High job satisfaction despite low income: A national study of Kenyan journalists. Journalism and Mass Communication Quarterly, 93(1), 164-186. https://doi.org/10.1177 /1077699015607334

Islam, S. ul, \& Ali, N. (2013). Motivation-Hygiene Theory: Applicability on Teachers. Journal of Managerial Sciences, 7(1), 87-104.

Jamal, A., \& Awaisi, R. (2012). The Challenges to Journalistic Professionalism: Between Independence and Difficult Work Conditions.

Jamil, S. (2018). Freedom of expression and threats to journalists' safety: an analysis of conflict reporting in journalism education in Pakistan. Journalism Studies, 6(2), 7-16. Retrieved from https://www.researchgate.net/publication/324836021_freedom-of-express

Journalism Pakistan. (2019). Unpaid for months, Geo staff goes on strike. Retrieved March 11, 2020, from https://www.journalismpakistan.com/unpaid-for-months-geo-staff-goes-on-strike

Khan. (2020). The Pathetic Plight of Working Journalists in Pakistan. Retrieved March 13, 2020, from https://antisystemic.org/satribune/www.satribune.com/archives/nov16_22_03/P1_newsmen.ht $\mathrm{m}$

Lavrakas, P. (2013). Convenience Sampling. In Encyclopedia of Survey Research Methods. https://doi.org/10.4135/9781412963947.n105

Liu, Y., Xiaoming, H., \& Wen, N. (2018). Professional impact and job satisfaction among Chinese journalists. Journalism, 19(9-10), 1344-1362. https://doi.org/10.1177/1464884916683550

McLeod, S. A. (2007). CT2 Paper 1 Maslow's Hierarchy of Needs. Simply Psychology, 1(1), 1-8. https://doi.org/10.1016/B978-0-88415-752-6.50250-2

McLeod, S. A. (2018). Maslow' s Hierarchy of Needs Maslow's Hierarchy of Needs. Business, 3-5. https://www.simplypsychology.org/maslow.html

McQuail. (2013). Journalism? How is it linked to society? 1-26. DOI: http://dx.doi.org/10.4135 19781526435798.n1

Memon, B. A. (2011). The role and status of journalists in Sindh Province, Pakistan. unpublished $\mathrm{Ph}$.D. thesis, Department of Media and Communication, University of Leicester.

Muala, I. Al. (2017). Job Stress in Journalism: Interaction between Organisational Support and Job Demands-Resources Model. Journal of Management and Sustainability, 7(4), 150. https://doi.org/10.5539/jms.v7n4p150

Murphy, C. (2019). Changing by the click: The professional development of UK journalists. Education Sciences, 9(4), 1-7. https://doi.org/10.3390/educsci9040249

n.d. (November 26, 2011). Journalists seek secure working conditions. Dawn (newspaper) https://www.dawn.com/news/676160/journalists-seek-secure-working-conditions

n.d. (2016). Violence, threats, and pressures against journalists and other media actors in the EU Contribution to the second Annual Colloquium. report published by FRA: European Union Agency For Fundamental Rights. Retrieved from https://fra.europa.eu/sites/default/files /fra_uploads/fra-2016-threats-and-pressures-journalists_en.pdf

Ofili, A., Tobin, E., Ilombu, M., Igbinosun, E., \& Iniomor, I. (2014). Assessment of job satisfaction, job stress, and psychological health of journalists in South-South, Nigeria. International Journal of Medicine and Biomedical Research, 3(3), 209-218. https://doi.org/10.14194 /ijmbr.3.3.9

Rameez, A., Huda, U., \& Ali, R. A. (2015). Portrayal of Women in Pakistani Media. International Journal of Academic Research and Reflection, 3(1), 12-18. Retrieved from www.idpublications.org

Rehmat, A., \& Alam, M. A. (2014). Supporting Safety of Journalists in Pakistan - An Assessment based on UNESCO 's Journalists ' Safety Indicators. 1-96.

Resources, M. L. (2016). CONNECT!ONS / Med!aLit Moments. Consortium for Media Literacy, (79), 1-14.

Rotwilm, P. (2014). The Future of Journalistic Work: Its Changing Nature and Implications. 
(August), 28. Retrieved from http://reutersinstitute.politics.ox.ac.uk/sites/default/files/ research/files/The\%2520Future\%2520of\%2520Journalistic\%2520Work\%2520-\%2520Its\%25 20Changing\%2520Nature\%2520and\%2520Implications.pdf

Schallom, R. (2012). Satisfaction and Journalism: a Study of Newsroom Happiness and Its Implications in Print Design. University of Missouri School of Journalism - Master of Arts, (December), 71.

Shalini, S. (2017). Factorial Analysis of Professional Stress in Journalism ( A Study on Media Journalists of India ). 22(8), 41-46. https://doi.org/10.9790/0837-2208144146

Shameer, S. M. (2018). Working Conditions of Journalists As a Research Field: Review Literature. $5(3), 630-636$.

Siddiqui, F. A. (2016). Threats to Journalists in India: Journalism in the Age of Intolerance and Rising Nationalism Sponsor: Thomson Reuters Foundation. Retrieved from https://reutersinstitute.politics.ox.ac.uk/sites/default/files/2018-08/Threats to Journalists in India Journalism in the Age of Intolerance and Rising Nationalism.pdf

Sonnemaker, T. (2015). Scholarship @ Claremont Objectivity and the Role of Journalism in Democratic Societies. Retrieved from http://scholarship.claremont.edu/cmc_theses/1057

Spilsbury, M. (2014). Emerging Skills for Journalists. (September). Retrieved from http://www.nctj .com/downloadlibrary/NCTJ Emerging Skills FINAL.pdf

Swedberg, R. (2018). On the uses of exploratory research and exploratory studies in social science. Producing Knowledge, pp. 1-37.

Taormina, R. J., \& Gao, J. H. (2013). Maslow and the motivation hierarchy: Measuring the satisfaction of the needs. American Journal of Psychology, 126(2), 155-177. https://doi.org/10.5406/amerjpsyc.126.2.0155

The Express Tribune. (2020). Internal threats: 'Journalists have to fight through job insecurity' | The Express Tribune. Retrieved March 12, 2020, from https://tribune.com.pk/story/780613 /internal-threats-journalists-have-to-fight-through-job-insecurity/

Thurman, N., Cornia, A., \& Kunert, J. (2016). Journalists in the UK. London: Reuters Institute for the Study of Journalism, 60. Retrieved from http://reutersinstitute.politics.ox.ac.uk/sites/default/ files/research/files/Journalists

Vijayan, M. (2017). Impact of Job Stress on Employees' Job Performance in Aavin, Coimbatore. Journal of Organization and Human Behavior, 6(3), 21-29. Retrieved March 12, 2020, from https://www.researchgate.net/publication/325734383_IMPACT_OF_JOB_STRESS_ON_EM PLOYEES'_JOB_PERFORMANCE_IN_AAVIN_COIMBATORE

Vogel, L. (2017). Journalism, an increasingly precarious profession.

von Rimscha, M. B. (2015). The Impact of Working Conditions and Personality Traits on the Job Satisfaction of Media Professionals. Media Industries Journal, 2(2). https://doi.org/ 10.3998/mij.15031809.0002.202

Wahl-Jorgensen, K., Williams, A., Sambrook, R., Harris, J., Garcia-Blanco, I., Dencik, L., ... Allan, S. (2016). The Future of Journalism: Risks, threats, and opportunities. Journalism Studies, 17(7), 801-807. https://doi.org/10.1080/1461670X.2016.1199486

Young, S., \& Carson, A. (2018). What is a Journalist?: The view from employers as revealed by their job vacancy advertisements. Journalism Studies, 19(3), 452-472. https://doi.org/10.1080/ 1461670X.2016.1190665 